\title{
PENGEMBANGAN LKPD BERBASIS MODEL ARCS PADA POKOK BAHASAN KESETIMBANGAN ION DAN PH LARUTAN PENYANGGA
}

\author{
Sasya Hanifha ${ }^{1 *}$, Susilawati ${ }^{2}$, Jimmi Copriady ${ }^{3}$ \\ ${ }^{123}$ Pendidikan Kimia, Universitas Riau \\ Email: sasyahanifha27@gmail.com
}

\begin{abstract}
Abstrak
Penelitian ini bertujuan untuk mengembangkan LKPD berbasis model ARCS pada pokok bahasan kesetimbangan ion dan $\mathrm{pH}$ larutan penyangga, mengetahui kevalidan LKPD berdasarkan aspek isi, karakteristik ARCS, kebahasaan, penyajian, kegrafisan dan mengetahui respon pengguna terhadap LKPD berbasis model ARCS pada pokok bahasan kesetimbangan ion dan $\mathrm{pH}$ larutan penyangga. Jenis penelitian ini adalah Research and Development $(R \& D)$ dengan model pengembangan 4-D. Objek penelitian ini adalah LKPD berbasis model ARCS. Adapun instrumen pengumpulan data berupa lembar validasi yang diberikan kepada tiga validator dan angket respon pengguna yang diberikan kepada guru dan peserta didik. Setelah dilakukan revisi sebanyak dua kali diperoleh hasil validitas pada aspek isi, karakteristik ARCS, kebahasaan, penyajian dan kegrafisan berturut-turut yaitu 93,75\%, 93,75\%, 98,33\%, $97,92 \%$ dan $98 \%$, sehingga diperoleh skor rata-rata $96,33 \%$ dengan kriteria valid. LKPD yang dinyatakan valid oleh validator dilakukan uji satu-satu kepada 3 orang peserta didik yang sudah mempelajari materi kesetimbangan ion dan $\mathrm{pH}$ larutan penyangga. Selanjutnya meminta respon kepada 3 orang guru kimia dan 20 peserta didik menghasilkan respon guru dan respon peserta didik sebesar $91,07 \%$ dan $79,73 \%$ dengan kriteria sangat baik. Berdasarkan hasil analisis data disimpulkan bahwa LKPD berbasis model ARCS dinyatakan valid dan dapat digunakan saat pembelajaran kimia SMA pada pokok bahasan kesetimbangan ion dan $\mathrm{pH}$ larutan penyangga.
\end{abstract}

Kata kunci: Larutan Penyangga, ARCS, LKPD

\begin{abstract}
This study aims to develop student worksheets based on the ARCS model on ionic equilibrium and pH of the buffer solution subject, determining the validity of student worksheets of the aspects of content, ARCS characteristics, language, presentation, graphics and find out user responses through student worksheets based on ARCS models on ionic equilibrium and $\mathrm{pH}$ buffer solution subject. This research is a Research and Development $(R \& D)$ with a 4-D development model. The object of this research is student worksheets based on the ARCS model. The data collection instruments were in the form of validation sheets given to three validators and user questionnaires given to teachers and students. After two revisions, the validity results obtained in the aspects of content, ARCS characteristics, language, presentation and graphics, respectively, namely 93.75\%, 93.75\%, 98.33\%, 97.92\% and 98\%. the average score was $96.33 \%$ that comes to valid criteria. student worksheets which was valid by the validator tested one by one on 3 students who had studied the ion balance and $\mathrm{pH}$ of the buffer solution. Furthermore, asking for response to 3 chemistry teachers and 20 students resulted the teacher's response and resultied a student response $91.07 \%$ and $79.73 \%$ that comes to very good criteria. Based on the results of the data analysis, it concluded that student worksheets based on the ARCS model was valid and can be used during high school chemistry lessons on the ion balance and $\mathrm{pH}$ of buffer solution subject.
\end{abstract}

Key words: Buffer Solution, ARCS, student worksheets 


\section{Pendahuluan}

Pembelajaran merupakan proses interaksi peserta didik dengan pendidik dan sumber belajar pada suatu lingkungan belajar. Pembelajaran adalah proses untuk membantu peserta didik agar dapat belajar dengan baik. Menurut Andi Prastowo (2012) bahan ajar adalah seperangkat materi yang disusun secara sistematis, baik tertulis maupun tidak tertulis sehingga tercipta lingkungan atau suasana yang memungkinkan peserta didik untuk belajar. Menurut bentuknya bahan ajar dibedakan kedalam empat macam, diantaranya bahan ajar cetak, bahan ajar dengar, bahan ajar pandang dengar, dan bahan ajar interaktif. Bahan ajar cetak adalah bahan ajar yang disajikan dalam kertas, yang berfungsi untuk menyampaikan informasi atau keperluan pembelajaran. Salah satu bahan ajar cetak yang sering digunakan adalah Lembar Kegiatan Peserta Didik (LKPD).

Hasil observasi di SMA Negeri 2 Tambang ditemukan fakta bahwa guru telah menggunakan LKPD dalam proses pembelajaran. Namun LKPD yang digunakan guru masih memiliki kekurangan yaitu tidak memenuhi syarat-syarat pembuatan LKPD yang baik meliputi syarat didaktik, syarat konstruksi dan syarat teknis.

Solusi untuk mengatasi permasalahan tersebut yaitu dengan mengembangkan suatu bahan ajar yang dapat meningkatkan motivasi belajar peserta didik. LKPD dapat dipilih menjadi salah satu alternatif untuk melaksanakan kegiatan pembelajaran. Salah satu upayanya adalah dengan membuat inovasi pada LKPD yang harus memenuhi syarat-syarat dan dapat meningkatkan motivasi belajar dengan melakukan pengembangan LKPD berbasis Model ARCS. Model ARCS memiliki empat komponen yang dapat membangkitkan motivasi belajar peserta didik, empat komponennya yaitu attention (perhatian/membangkitkan dan mempertahankan perhatian siswa selama pembelajaran), relevance (mengaitkan pembelajaran dengan kebutuhan siswa), confidence (menumbuhkan rasa percaya diri siswa), dan satisfaction (membangkitkan rasa puas siswa terhadap pembelajaran) (Keller, 2010).

Penelitian terdahulu yang berkaitan telah dilakukan oleh Riki dkk. (2016) yaitu pengembangan modul fisika berorientasi pada model motivasi ARCS (Attention, Relevance, Confidence, Satisfaction) pokok bahasan suhu dan kalor siswa kelas $\mathrm{X}$ SMA. Hasil penilitian ini menyimpulkan bahwa tingkat kelayakan modul pada aspek 
materi dan media berturut-turut sebesar $87,4 \%$ dan $87,5 \%$ dengan kategori sangat layak. Tingkat keterbacaan modul pada uji coba kelompok kecil sebesar $98,4 \%$ dan 99,3\% pada uji coba kelompok besar dengan kategori keterbacaan tinggi. Respon siswa terhadap modul pada uji coba kelompok kecil sebesar $90,9 \%$ dan $91,9 \%$ pada uji coba kelompok besar dengan kategori sangat baik. LKPD memuat kegiatan yang harus dilakukan peserta didik untuk memaksimalkan pemahaman dalam upaya pembentukan kemampuan dasar sesuai indikator pencapaian hasil belajar yang harus ditempuh. LKPD sangat penting untuk mengetahui pencapaian peserta didik dalam memahami materi yang telah diberikan. Sehingga, dibutuhkan LKPD yang ideal sesuai dengan standar yang telah ditetapkan (Slamet Widodo, 2017).

Berdasarkan pemaparan di atas, peneliti telah melakukan penelitian berupa "Pengembangan LKPD berbasis Model ARCS Pada Pokok Bahasan Kesetimbangan Ion dan pH Larutan Penyangga".

\section{Metode Penelitian}

Penelitian telah dilaksanakan di Fakultas Keguruan dan IImu Pendidikan (FKIP) Program Studi Pendidikan Kimia Universitas Riau dengan uji coba satu-satu di SMA Negeri 2 Tambang dan uji coba terbatas di SMA Negeri 2 Tambang dan SMA Negeri 5 Pekanbaru. LKPD berbasis model ARCS ini menggunakan model pengembangan 4-D yang dikemukakan oleh Thiagarajan dan Semmel. Tahapan dari model pengembangan 4-D ini terdiri dari empat tahapan yaitu Define, Design, Develop, dan Disseminate. Namun penelitian dilakukan hanya sampai tahap ketiga yaitu tahap pengembangan (Develop), sedangkan tahap penyebaran (Disseminate) tidak dilakukan karena tujuan dibatasi hingga dihasilkan LKPD yang valid menurut validator dan baik menurut respon pengguna. Penelitian pengembangan dengan model 4-D dipilih karena cocok untuk mengembangkan perangkat pembelajaran dan juga tahapan-tahapan pengembangannya sederhana dan mudah dipahami. 


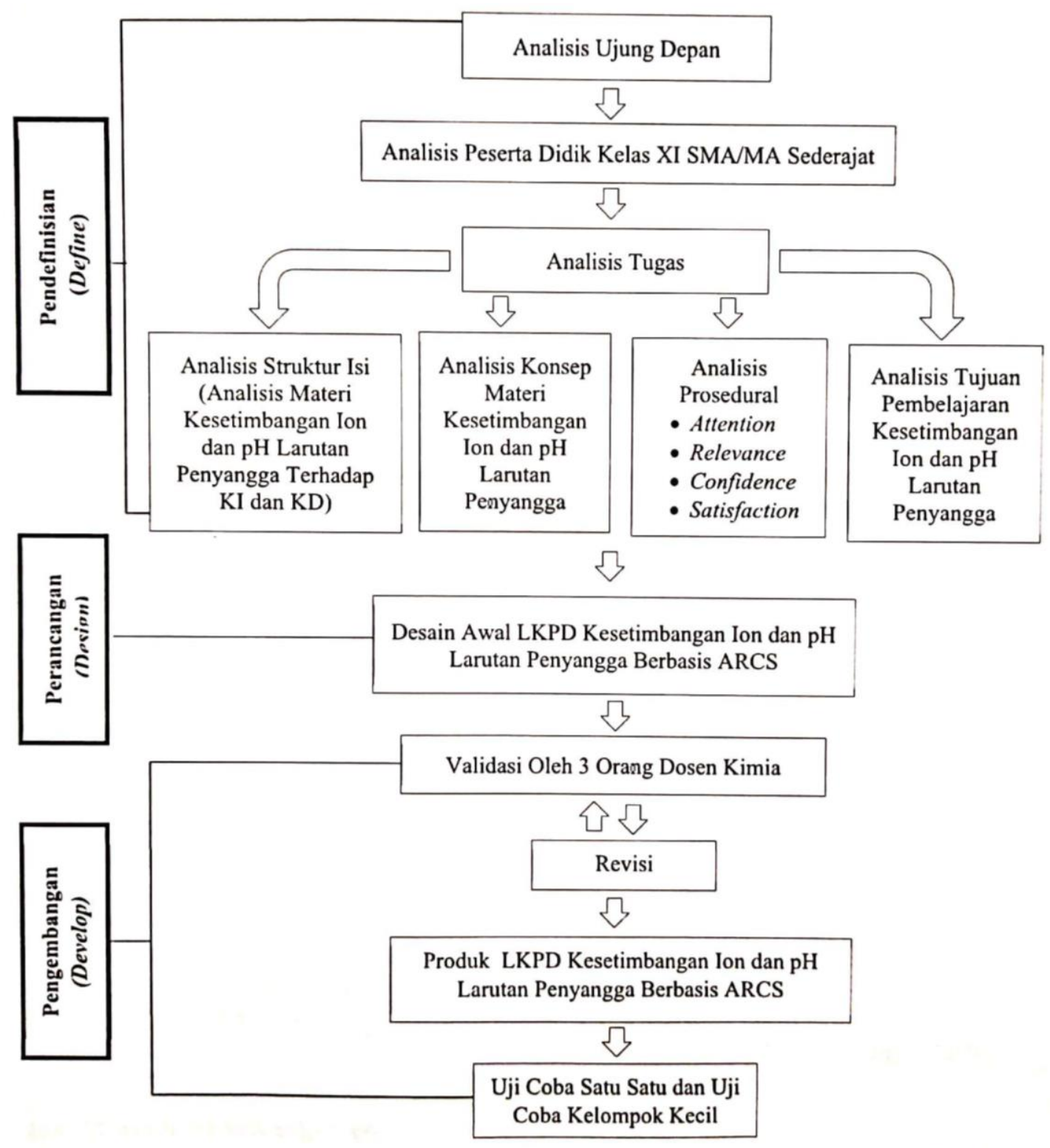

Gambar 1. Alur Pengembangan Lembar Kegiatan Peserta Didik (Modifikasi Trianto, 2012)

Data yang dirangkum terkait validasi dan uji coba terbatas terhadap LKPD berbasis model ARCS pada pokok bahasan kesetimbangan ion dan ph larutan penyangga diperoleh pada tahap pengembangan yaitu validasi, revisi dan uji coba menggunakan instrumen penelitian berupa lembar validasi oleh 3 orang validator, angket respon pengguna oleh guru dan peserta didik. Teknik analisis data yang digunakan dalam penelitian ini adalah analisis deskriptif yang bertujuan untuk mendeskripsikan hasil validitas yang diberikan oleh validator setelah divalidasi. 
Analisis validitas menurut Riduwan (2012) yaitu:

$$
\text { Persentase }=\frac{\text { jumlah skor yang diperoleh }}{\text { jumlah skor maksimum }} \times 100 \%
$$

Persentase yang diperoleh kemudian dikonversi menjadi nilai kualitatif dengan kriteria validitas pada tabel 1 .

Tabel 1. Kriteria Validitas

\begin{tabular}{ll}
\hline \multicolumn{1}{c}{ Persentase } & Keterangan \\
\hline $80,00-100$ & Baik/Valid \\
$60,00-79,99$ & Cukup Baik/Cukup Valid \\
$60,00-59,99$ & Kurang Baik/Kurang Valid \\
$0-49,99$ & Tidak Baik (Diganti) \\
\hline
\end{tabular}

(Riduwan, 2012)

Analisis respon pengguna menggunakan skala Likert dengan penskoran yang disajikan pada tabel 2.

Tabel 2. Skor Alternatif Pernyataan Positif

\begin{tabular}{lc}
\hline Pernyataan Sikap & Skor \\
\hline SS : Sangat Setuju & 4 \\
S : Setuju & 3 \\
KS: Kurang Setuju & 2 \\
TS: Tidak Setuju & 1
\end{tabular}

(Eko Putro Widoyoko, 2017)

Persentase yang diperoleh kemudian dikonversi menjadi nilai kualitatif dengan kriteria validitas pada tabel 3 .

Tabel 3. Kriteria Respon Pengguna

\begin{tabular}{ll}
\hline Rata-Rata Skor (\%) & Kriteria Respon Pengguna \\
\hline $75,00-100$ & Sangat Baik \\
$50,00-74,99$ & Baik \\
$25,00-49,99$ & Kurang Baik \\
$0,00-24,99$ & Tidak Baik
\end{tabular}

(Yuni Yamasari, 2010) 


\section{Hasil dan Pembahasan}

Produk yang dihasilkan dari penelitian ini berupa LKPD berbasis model ARCS pada pokok bahasan Kesetimbangan lon dan $\mathrm{pH}$ Larutan Penyangga kelas XI SMA/MA sederajat yang dapat digunakan saat proses pembelajaran. Hasil dan pembahasan dari setiap tahapann pengembangan yang telah dilakukan:

\section{Tahap Pendefinisian (Define)}

- Analisis Ujung Depan

Analisis ujung depan telah dilakukan melalui wawancara terhadap tiga orang guru kimia, informasi dan data yang diperoleh bahwa guru sudah menggunakan LKPD baik bersifat eksperimen dan noneksperimen pada beberapa materi pembelajaran kimia, salah satunya pada materi kesetimbangan ion dan $\mathrm{pH}$ larutan penyangga. Akan tetapi LKPD yang dibuat oleh guru belum memenuhi syarat-syarat yang harus dipenuhi dan hanya berisi ringkasan materi, terlihat kurang menarik dan beberapa pertanyaan sehingga membuat peserta didik tidak termotivasi dalam belajar yang akan membuat peserta didik lebih sulit memahami pembelajaran dikarenakan pembelajaran kimia yang bersifat abstrak.

- Analisis Peserta Didik

Peserta didik atau pengguna produk LKPD kesetimbangan ion dan $\mathrm{pH}$ larutan penyangga adalah peserta didik kelas XI MIPA SMA Negeri 2 Tambang dan XI MIPA SMA Negeri 5 Pekanbaru yang memiliki rentang usia 16-17 tahun. Teori perkembangan kognitif Piaget menjelaskan bahwa peserta didik terletak pada tahap operasional formal. Pada usia ini peserta didik mendekati efisiensi intelektual yang maksimal, namun karena kurangnya pengalaman sehingga membatasi pengetahuan dan kecakapannya untuk memanfaatkan apa yang diketahui. Banyak hal yang dapat dipelajari melalui pengalaman, tetapi peserta didik tersebut kadang kala mengalami kesulitan dalam memahami konsep-konsep abstrak (Sujiono dkk, 2008).

- Analisis Tugas

Analisis tugas terdiri dari :

Pertama, Analisis struktur isi yaitu menganalisis kurikulum terhadap Kompetensi Isi $(\mathrm{KI})$, dan Kompetensi Dasar (KD) terkait materi yang akan dikembangkan yaitu materi kesetimbangan ion dan $\mathrm{pH}$ larutan penyangga kelas XI SMA/MA semester 
genap. Kedua, analisis konsep yaitu mengidentifikasi konsep-konsep utama materi kesetimbangan ion dan $\mathrm{pH}$ larutan penyangga sesuai dengan kurikulum 2013 pada KD 3.12 dan 4.12 yang akan diajarkan serta disusun secara sistematis dalam bentuk peta konsep. Ketiga, analisis prosedural yaitu tahap/langkah untuk menyelesaikan tugas dan menemukan konsep yang digunakan pada LKPD berbasis model ARCS terdiri dari Attention, Relevance, Confidence and Satisfaction. Keempat, analisis tujuan yaitu menghasilkan suatu tujuan pembelajaran dan IPK yang harus dicapai peserta didik dan telah dirumuskan berdasarkan Kompetensi Dasar (KD 3.12 dan 4.12)

\section{Tahap Perancangan (Design)}

Penyusunan LKPD menghasilkan komponen LKPD yang mencakup 1) judul, 2) petunjuk belajar, 3) tujuan pembelajaran, 4) materi, 5) kegiatan pembelajaran, 6) kolom penilaian dan 7) daftar pustaka. Desain instrumen berupa kisi-kisi lembar validasi dan desain angket respon pengguna untuk guru dan peserta didik.

\section{Tahap Pengembangan (Develop)}

Validasi LKPD

Validasi bertujuan untuk memperoleh penilaian dan saran terhadap LKPD berbasis model ARCS pada pokok bahasan kesetimbangan ion dan $\mathrm{pH}$ larutan penyangga kelas XI SMA/MA sederajat oleh tim validator yang terdiri dari 2 orang dosen Universitas Riau dan 1 orang dosen Universitas Islam Riau. Validasi telah dilakukan sebanyak dua kali pada masing-masing validator. Berikut uraian hasil validasi setiap aspek.

- Aspek Isi

Penilaian dari validator pada aspek isi dapat dilihat pada tabel 4 .

Tabel 4. Validasi Aspek Isi

\begin{tabular}{lcc}
\hline \multicolumn{1}{c}{ Komponen Penilaian } & Validasi 1 & Validasi 2 \\
\cline { 2 - 3 } & Persentase (\%) & Persentase (\%) \\
\hline $\begin{array}{l}\text { LKPD sesuai dengan Kompetensi Dasar (KD) } \\
\text { dan Indikator Pencapaian Kompetensi (IPK) }\end{array}$ & 83,33 & 100 \\
\hline $\begin{array}{l}\text { Rumusan tujuan pembelajaran pada LKPD } \\
\text { selaras dengan indikator }\end{array}$ & 75 & 100 \\
\hline LKPD sesuai dengan substansi pokok & 83,33 & 100 \\
\hline
\end{tabular}




\begin{tabular}{|c|c|c|}
\hline Komponen Penilaian & \begin{tabular}{|c|} 
Validasi 1 \\
Persentase (\%)
\end{tabular} & \begin{tabular}{|c|} 
Validasi 2 \\
Persentase (\%)
\end{tabular} \\
\hline $\begin{array}{l}\text { bahasan kesetimbangan ion dan } \mathrm{pH} \text { larutan } \\
\text { penyangga }\end{array}$ & & \\
\hline $\begin{array}{l}\text { LKPD dapat mengarahkan peserta didik } \\
\text { untuk mencari informasi }\end{array}$ & 66,67 & 83,33 \\
\hline $\begin{array}{l}\text { LKPD memuat konsep yang berhubungan } \\
\text { dengan kehidupan sehari-hari }\end{array}$ & 58,33 & 75 \\
\hline $\begin{array}{l}\text { LKPD memiliki kegiatan yang memungkinkan } \\
\text { peserta didik untuk aktif (menimbulkan rasa } \\
\text { ingin tahu, memiliki keterampilan bertanya } \\
\text { dan menyatakan pendapat) dalam kegiatan } \\
\text { pembelajaran) }\end{array}$ & 91,67 & 100 \\
\hline $\begin{array}{l}\text { LKPD memiliki kegiatan yang dapat menjalin } \\
\text { komunikasi antara peserta didik dengan guru } \\
\text { dan peserta didik lainnya }\end{array}$ & 75 & 91,67 \\
\hline $\begin{array}{l}\text { Pertanyaan yang ada memberikan petunjuk } \\
\text { untuk menemukan konsep }\end{array}$ & 75 & 100 \\
\hline Rata-rata Persentase Skor Total & $76,04 \%$ & $93,75 \%$ \\
\hline
\end{tabular}

Pada tabel 4. menunjukkan bahwa rata-rata persentase skor total untuk validasi I sebesar $76,04 \%$ dengan kriteria cukup valid. Validasi II menunjukkan rata-rata persentase skor total yang lebih tinggi dari validasi I yakni 93,75\% dengan kriteria valid. Komponen penilaian yang memiliki skor validasi terendah adalah "LKPD memuat konsep yang berhubungan dengan kehidupan sehari-hari". Indikator tersebut memperoleh nilai validitas sebesar $75 \%$. Hal ini disebabkan karena pada LKPD hanya tahap Relevance saja yang memuat konsep yang berhubungan dengan kehidupan sehari-hari dan tahap lainnya belum memuat konsep yang berhubungan dengan kehidupan sehari-hari.

- Aspek Karakteristik ARCS

Penilaian dari validator pada aspek isi dapat dilihat pada tabel 5 
Tabel 5. Validasi Aspek Karakteristik ARCS

\section{Komponen Penilaian}

Validasi $1 \quad$ Validasi 2

Persentase (\%) Persentase (\%)

Tahapan Attention memfasilitasi peserta didik

91,67

100

untuk meningkatkan perhatian

Tahapan Relevance memfasilitasi peserta

83,33

91,67

didik untuk mengetahui manfaat pengetahuan

yang dipelajari

Tahapan Confidence memfasilitasi peserta

91,67

100

didik untuk meningkatkan kepercayaan diri

Tahap Satisfaction memfasilitasi peserta didik

66,67

83,33

untuk mempresentasikan hasil/solusi dari

penyelesaian masalah kepada peserta didik

lainnya

Rata-rata Persentase Skor Total

$83,33 \%$

$93,75 \%$

Pada tabel 5. menunjukkan bahwa rata-rata persentase skor total untuk validasi I sebesar $83,33 \%$ dengan kriteria valid. Validasi II menunjukkan rata-rata persentase skor total yang lebih tinggi dari validasi I yakni 93,75\% dengan kriteria valid. Komponen penilaian yang memiliki skor validasi terendah adalah "tahap Satisfaction memfasilitasi peserta didik untuk mempresentasikan hasil/solusi dari penyelesaian masalah kepada peserta didik lainnya". Indikator tersebut memperoleh nilai validitas sebesar $83,33 \%$. Hal ini disebabkan karena tahapan satisfaction belum sangat baik untuk memfasilitasi peserta didik dalam mempresentasikan hasil pengamatannya bersama guru dan peserta didik lainnya karena hanya memberikan perintah mengisi tabel hasil presentasi.

- Aspek Bahasa

Penilaian dari validator pada aspek isi dapat dilihat pada tabel 6.

Tabel 6. Validasi Aspek Bahasa 


\section{Persentase (\%) Persentase (\%)}

\begin{tabular}{lllll}
\hline Bahasa yang digunakan menarik dan & 83,33 & 91,67
\end{tabular}
komunikatif

Bahasa yang digunakan sesuai dengan $83,33 \quad 100$

Kaidah Bahasa Indonesia yang baik dan benar

\begin{tabular}{lcc}
\hline $\begin{array}{l}\text { LKPD menggunakan bahasa yang sesuai } \\
\text { dengan tingkat kemampuan peserta didik }\end{array}$ & 100 & 100 \\
\hline $\begin{array}{l}\text { LKPD menggunakan struktur kalimat yang } \\
\text { jelas }\end{array}$ & 100 & 100 \\
\hline $\begin{array}{l}\text { Bahasa yang digunakan pada LKPD } \\
\text { sederhana dan mudah dipahami peserta didik }\end{array}$ & 91,67 & 100 \\
\hline Rata-rata Persentase Skor Total & $\mathbf{9 1 , 6 7 \%}$ & $\mathbf{9 8 , 3 3 \%}$
\end{tabular}

Pada tabel 6. menunjukkan bahwa rata-rata persentase skor total untuk validasi I sebesar $91,67 \%$ dengan kriteria valid. Validasi II menunjukkan rata-rata persentase skor total yang lebih tinggi dari validasi I yakni 98,33\% dengan kriteria valid. Komponen penilaian yang memiliki skor validasi terendah adalah "bahasa yang digunakan menarik dan komunikatif". Indikator tersebut memperoleh nilai validitas sebesar $91,67 \%$. Hal ini dikarenakan tidak semua bahasa yang digunakan pada LKPD bersifat komunikatif. Seperti penulisan nama senyawa asam dan basa, tidak semua peserta didik yang dapat membaca nama dari struktur senyawa asam dan basa

- Aspek Penyajian

Penilaian dari validator pada aspek isi dapat dilihat pada tabel 7 .

Tabel 7. Validasi Aspek Penyajian

Komponen Penilaian

Validasi $1 \quad$ Validasi 2

Persentase (\%) Persentase (\%) 


\section{Komponen Penilaian}

\section{Validasi $1 \quad$ Validasi 2}

\section{Persentase (\%) Persentase (\%)}

Kesesuaian penggunaan ilustrasi dengan

83,33

100

materi pada LKPD

Kelengkapan format LKPD (judul, daftar isi, 83,33

100

indikator pencapaian kompetensi, petunjuk

LKPD/ petunjuk belajar, tujuan pembelajaran

yang ingin dicapai, materi, latihan, penilaian

dan daftar pustaka)

LKPD menyediakan ruang yang cukup untuk

100

100

memberi keluasan bagi peserta didik untuk

menulis maupun menggambarkan hal-hal

yang ingin disampaikan oleh peserta didik

Kejelasan tulisan dan gambar pada LKPD

83,33

91,67

Rata-rata Persentase Skor Total

$87,50 \%$

$97,92 \%$

Pada tabel 7. menunjukkan bahwa rata-rata persentase skor total untuk validasi I sebesar $87,50 \%$ dengan kriteria valid. Validasi II menunjukkan rata-rata persentase skor total yang lebih tinggi dari validasi I yakni 97,92\% dengan kriteria valid. Komponen penilaian yang memiliki skor validasi terendah adalah "kejelasan tulisan dan gambar pada LKPD". Indikator tersebut memperoleh nilai validitas 91,67\%. Hal ini disebabkan karena tulisan dan gambar pada LKPD sudah baik namun gambar peranan larutan penyangga dalam tubuh makhluk hidup yang bersifat abstrak sulit untuk dijelaskan karena hanya menampilkan gambar darah dan paru-paru saja.

- Aspek Kegrafisan

Penilaian dari validator pada aspek isi dapat dilihat pada tabel 8.

Tabel 8. Validasi Aspek Kegrafisan 


\begin{tabular}{lcc}
\hline & Persentase (\%) & Persentase (\%) \\
\hline $\begin{array}{l}\text { LKPD menggunakan jenis dan ukuran huruf } \\
\text { yang baik dan menarik }\end{array}$ & 83,33 & 100 \\
\hline $\begin{array}{l}\text { LKPD memiliki tata letak (layout) yang } \\
\text { menarik }\end{array}$ & 83,33 & 100 \\
\hline $\begin{array}{l}\text { LKPD memiliki ilustrasi/ gambar/ foto yang } \\
\text { baik dan berhubungan dengan konsep }\end{array}$ & 83,33 & 91,67 \\
\hline $\begin{array}{l}\text { LKPD memiliki desain tampilan yang } \\
\text { menarik }\end{array}$ & 83,33 & 100 \\
\hline \multicolumn{2}{l}{ Rata-rata Persentase Skor Total } & $\mathbf{8 3 , 3 3 \%}$ \\
\hline
\end{tabular}

Pada tabel 8 skor rata-rata validasi I aspek kegrafisan adalah 83,33\% dan termasuk kriteria valid. Setelah dilakukan revisi, skor rata-rata validasi II pada aspek kegrafisan adalah $97,92 \%$ dan termasuk kriteria valid. Komponen penilaian yang memiliki skor validasi terendah adalah "LKPD memiliki ilustrasi/gambar/foto yang baik dan berhubungan dengan konsep". Indikator tersebut memperoleh nilai validitas $91,67 \%$. Hal ini dikarenakan masih terdapat gambar yang tidak berhubungan dengan konsep seperti gambar kartun pada dialog percakapan.

Diagram rata-rata hasil validasi LKPD dari berbagai aspek oleh validator disajikan pada gambar 2.

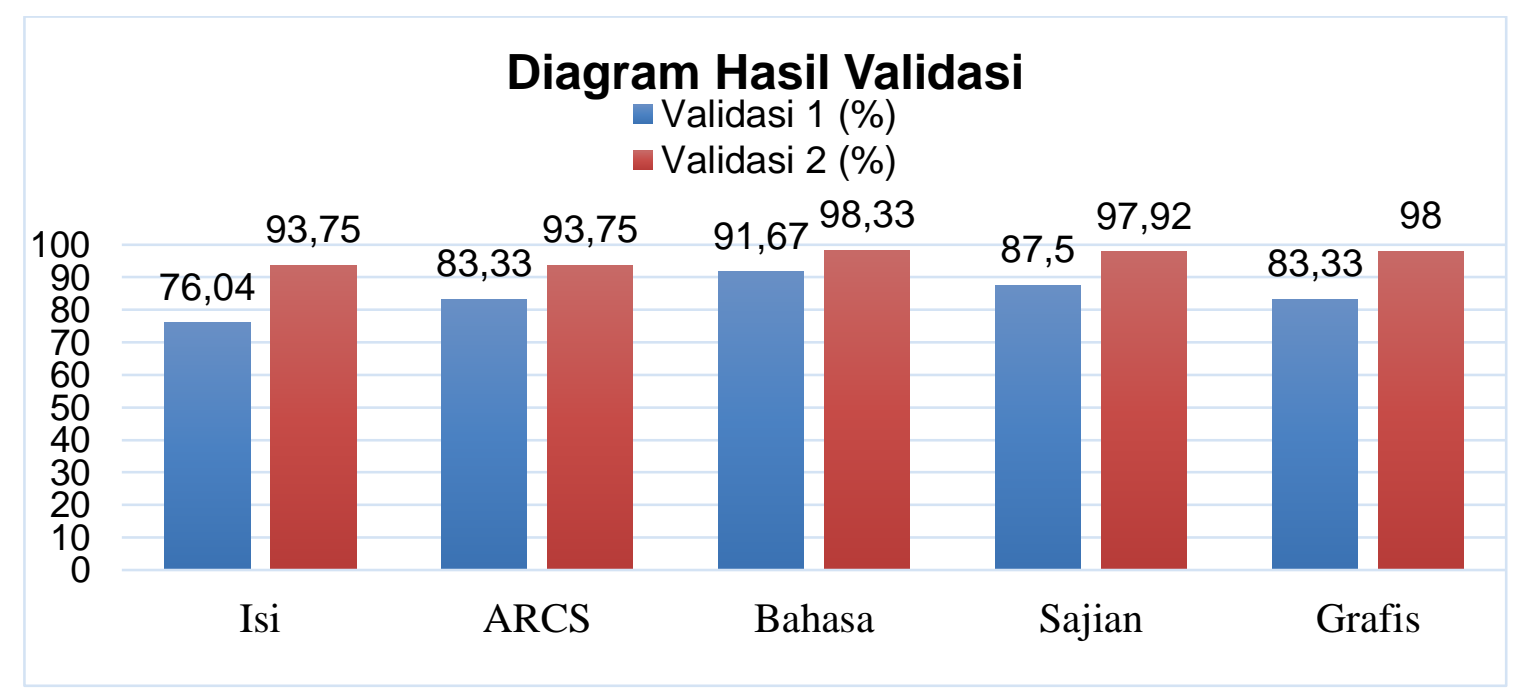

Gambar 2. Diagram Hasil Skor Validasi LKPD pada Berbagai Aspek 
Setelah LKPD selesai divalidasi oleh tim validator dan direvisi oleh peneliti, maka dilakukan uji coba satu-satu kepada 3 orang peserta didik yang sudah mempelajari materi kesetimbangan ion dan $\mathrm{pH}$ larutan penyangga dengan kemampuan kompetensi berbeda untuk mengerjakan LKPD yang telah dinyatakan valid oleh validator. Tahap uji coba satu-satu dihasilkan bahwa kejelasan materi pada LKPD sudah jelas, soal-soal yang ada pada LKPD dapat dikerjakan oleh peserta didik. Komentar dan hasil wawancara terhadap peserta didik pada uji coba satu-satu disajikan pada tabel 9.

Tabel 9. Komentar dan saran Hasil Uji Coba Satu-Satu

\section{PD Komentar dan Hasil Wawancara}

\begin{tabular}{cl}
\hline 1 & $\begin{array}{l}\text { Perhatikan tabel jawaban LKPD agar ukurannya lebih dibesarkan } \\
\text { khususnya LKPD } 3 \text { pada tabel menjawab pertanyaan soal pertama }\end{array}$ \\
\hline 2 & Tambahkan alokasi waktu \\
\hline 3 & Soal pada LKPD 3 terlalu banyak
\end{tabular}

Selanjutnya meminta respon kepada 3 orang guru kimia dan kepada 20 orang peserta didik yang sudah mempelajari materi kesetimbangan ion dan $\mathrm{pH}$ larutan penyangga terhadap LKPD yang telah dikembangkan. Berikut disajikan ke dalam tabel hasil yang diperoleh dari masing-masing respon pengguna yaitu:

Tabel 10. Rekapitulasi Hasil Uji Coba Respon Pengguna (guru dan Peserta didik)

\begin{tabular}{ccc}
\hline Responden & Hasil (\%) & Kategori \\
\hline Guru & $91,07 \%$ & Sangat Baik \\
Peserta Didik & $79,73 \%$ & Sangat Baik \\
\hline Rata-rata & $\mathbf{8 5 , 4 \%}$ & Sangat Baik \\
\hline
\end{tabular}

\section{Kesimpulan}

LKPD berbasis model ARCS pada pokok bahasan kesetimbangan ion dan $\mathrm{pH}$ larutan penyangga kelas XI SMA/MA yang dikembangkan dinyatakan valid menurut validator berdasarkan aspek isi, karakteristik ARCS, kebahasaan, penyajian dan kegrafisan dengan perolehan skor berturut-turut sebesar 93,75\%,93,75\%, 98,33\%, 
$97,92 \%$, dan $98 \%$. Hasil uji coba terhadap pengguna memperoleh persentase skor ratarata sebesar $91,07 \%$ oleh guru dengan kriteria sangat baik dan $79,73 \%$ oleh peserta didik dengan kriteria sangat baik. LKPD yang telah dihasilkan ini dapat digunakan dalam proses pembelajaran kimia pada pokok bahasan kesetimbangan ion dan $\mathrm{pH}$ larutan penyangga kelas XI SMA/MA.

\section{Daftar Referensi}

Andi Prastowo. 2012. Panduan Kreatif Membuat Bahan Ajar Inovatif. Diva Press. Yogyakarta.

Eko Putro Widoyoko. 2017. Teknik Penyusunan Instrumen Penilaian. Pustaka Belajar. Yogyakarta.

Keller, J. M. 2010. Motivational Design for Learning and Performance: The ARCS Model Approach. Springer. New York.

Riduwan. 2012. Skala Pengukuran Variabel-variabel Penelitian. Alfabeta. Bandung.

Riki Neneng Fadilah, Fahmi Yahya dan A Hamid Rahman. 2016. Pengembangan Modul

Fisika Berorientasi pada Model Motivasi ARCS (Attention, Relevance, Confidence,Satisfaction) Pokok Bahasan Suhu Dan Kalor Siswa Kelas X SMA. Prosiding Seminar Nasional Pendidikan. FKIP UNSA. NTB.

Slamet Widodo. 2017 Pengembangan Lembar Kegiatan Peserta Didik (LKPD) berbasis Pendekatan Saintifik untuk Meningkatkan Keterampilan Penyelesaian Masalah Lingkungan Sekitar Peserta Didik di Sekolah Dasar. Jurnal Pendidikan IImu Sosial. 26 (2): 189-204.

Sujiono Yuliani N, Opih Rofiah Zainal, E. Leony T dan Rita Rosmala. 2008. Metode Pengembangan Kognitif. Universitas Terbuka. Jakarta

Trianto. 2012. Model Pembelajaran Terpadu Konsep Strategi dan Implementasinya dalam KTSP. Bumi Aksara. Jakarta.

Yuni Yamasari. 2010. Pengembangan Media Pembelajaran Matematika Berbasis ICT yang Berkualitas. Prosiding Seminar Nasional Pascasarjana X-ITS ISBN No. 979-545-0270-1. FMIPA UNESA. Surabaya 